N. I. Chukhrai, Dr. Sc. (Econ.), Prof., orcid.org/0000-0001-8591-2487, O.Z. Sorochak, Cand. Sc. (Tech.), Assoc. Prof., orcid.org/0000-0003-2889-9284,

I. V. Bokhonko, Cand. Sc. (Econ.), orcid.org/0000-0001-9812-7592
National University 'L'viv Polytechnic', Lviv, Ukraine, e-mail: chuhraj@polynet.lviv.ua

\title{
METHODICAL APPROACHES TO DISTRIBUTION OF RESOURCES OF AN ENERGY SUPPLYING COMPANY TO REDUCE OPERATIONAL LOSSES
}

Despite the large number of works by leading Ukrainian and foreign scientists to reduce operational losses in electricity transmission, the expediency of further research is conditioned by the growing need for the allocation of investment resources between technical and technological solutions so as to achieve the optimal solution to this multi-purpose problem.

Purpose. To develop and test a model of targeted programming for optimal allocation of investment resources of the energy supply enterprise among different variants of technical and technological decisions on reducing operational losses in the transportation of electricity from its sources to consumers.

Methodology. The authors use the system and analytical method, the method of targeted programming, which makes it possible to distribute the investment resources of the energy supply enterprise.

Findings. As technical and technological solutions reflect the indicator of loss reduction, the authors propose to consider them in more detail. A model of targeted programming of resource allocation among these solutions has been developed. Thus, the proposed model of targeted programming provides the opportunity to make the most effective decisions by the management of power supply enterprises in order to minimize operational losses during the supply of electricity to consumers.

Originality. A model of optimal allocation of investment resources between technical and technological decisions concerning reduction of operational losses at power supply on the basis of the method of target programming is developed. This model allows one to distribute investment resources in such a way so as to satisfy the selected optimization criteria and achieve the best result for the energy supply company.

Practical value. The proposed model was implemented at 'Prykarpattiaoblenerho' PJSC energy supplying enterprise, and the obtained results allow solving problems of reduction of electric energy losses during transportation.

Keywords: electric power, electric energy transportation, operational losses, power supply enterprises, technical and technological solution, linear programming, target programming

Introduction. The operational losses of energy supply enterprises while transporting electricity from the generation sources to its consumers is an important factor that affects the final results of their activities; therefore, decision making to reduce these losses is fundamental.

Reducing losses in electricity supply can be achieved through organizational and managerial, administrative and technological, technical and technological decisions. Organizational and managerial decisions are connected with the management improvement of electrical network modes and electricity accounting, administrative and technological decisions - with the automation of electrical network modes control and electric networks maintenance improvement, technical and technological decisions - with the improving the technical condition of the networks for reducing electricity losses. These solutions can be combined into a system of alternative decisions for choosing the most effective one at a specific time. Taking into account the current technical condition of domestic electricity grids, technical and technological decisions for reducing operating losses during the electricity transportation are the most efficient, and at the same time, the most costly ones. Therefore, the managers of energy supply companies need to distribute the limited investment and labor resources allocated for updating the electricity grids, between specific technical and technological decisions. Aforesaid actualizes to develop recommendations for the enterprise resources allocation between technical and technological decisions by the method of targeted programming.

Literature review. Despite the current technical state of domestic electricity grids, technical and technological decisions for reducing operating losses during the electricity transportation are the most efficient and costly. The leaders of energy supply companies meet problem of distributing the limited investment and labor resources for updating the electricity

(C) Chukhrai N. I., Sorochak O.Z., Bokhonko I. V., 2019 grids between specific technical and technological decisions. The problem of reducing operational losses during electricity transportation was undertaken by such scientists: Astashev, D. S. [1], Bedretdinov, R. S. [1], Kisel, D.A. [1], Sosnina, E. N. [1], Kostetska, N. I. [2, 3], Levytska, I. O. [4, 5], Filippova, S. V. [6] and Yudin, M. A. [6]. The research works by these scientists concerned issues of under-accumulating electricity, the formation of losses norms and other aspects concerning increasing the energy supply efficiency. At the same time, the problem of investment resources distribution between different technical and technological decisions, which is a task of multi-purpose optimization, is not resolved.

Unsolved aspects of the problem. Despite a large number of research studies by leading Ukrainian and foreign scientists concerning reducing operational losses in the electricity transportation, the expediency of further research is conditioned by the growing need of distribution the investment resources between technical and technological solutions in order to achieve solution of this problem.

The purpose of this article is to develop methodological approaches and approbate them on the basis of target programming models for optimal investment resources of energy supplying enterprise distribution between different technical and technological decisions concerning operational losses reduction during transportation of electric energy from its sources to consumers.

Results. For better understanding of the peculiarities of impact on the operational losses reduction of energy supply companies based on certain technical and technological solutions, let us consider one of them. Currently 6.246 units of complete transformer substations (KTS) 6-10/0.4 kV are operated in networks of the public joint-stock company "Prykarpattiaoblenerho", 991 of them need to be reconstructed and 555 require full replacement [7]. Prolonged operation of KTS 6-10/0.4 kV, which have served their resources under the influence of external factors, leads to KTS panels aging and dam- 
age, their rust, which leads the power equipment failure, breaks in electrical supply and lack of electricity. In addition, the KTSs, which were built in the $60-70$-s of the last century, in many cases were executed in violation of the requirements of PUE permissible dimensions, these inconsistencies are often recorded by representatives of the State Energy Inspection. It has been established that at the KTS whose wear factor, according to the assessment of the technical condition, is more than $70 \%$ unscheduled repairs are carried out, the cost of which is an average of $3600 \mathrm{UAH} /$ year per one KTS annually. At the same time, each damage of KTS is accompanied by a mean loss of 2.68 thousand $\mathrm{kWh}$ of electricity per year. Thus, at the electricity cost of $1.68 \mathrm{UAH} / \mathrm{kWh}$, losses from non-consumption of electricity at the same time are 4502.4 UAH.

In addition, when deciding to replace worn-out KTSs with their current modifications, one should take into account that replacement of one KTS will allow the re-use of spare parts for dismantling, in particular: automatic switches, lightning dischargers, passage insulators, support insulators [8]. Assuming that $50 \%$ of dismantled elements will be suitable for re-using and their wear will not exceed $50 \%$, the cost of spare parts from replacing one KTS will be $2.960 \mathrm{UAH}$.

As we see from the example, the quality of the decision in our case is estimated by the following criteria: 1) annual savings in electricity losses; 2) annual savings in repairs; 3 ) the cost of materials returned from dismantling.

Then the choice of the best solution is a non-trivial task, there is a problem: what should be understood under the optimal solution? The fact is that it is not objectively known which solution is better, if there are many criteria and they may also be "conflicting". In particular, it is unclear what solution is best if we want to maximize all three of the above criteria at the same time by deciding on the distribution of a certain amount of investment resources allocated to replace the outdated or physically worn out energy equipment. Therefore, it is necessary to seek a compromise solution that takes into account the importance of each target function. Thus, we arrive at the notion of an effective (Pareto-optimal) solution [9]. The efficiency property (in the extreme case, the weak efficiency) must have any decision that claims to be called optimal. However, with this approach, there is a problem of choosing a single solution, since pareto-optimal solutions, as a rule, are many (often infinitely many). The problem of choosing one solution from a pareto-optimal can be solved, for example, using the target programming method. With this approach it is possible to construct one solution, which is pareto-optimal. It should be noted that target programming is not the only method of finding one pareto-optimal solution. In particular, there is a special theory of arbitration schemes, which also allows solving this problem [10]. In the case of a linear multi-criterion problem, it makes sense to talk about extreme effective (pareto-optimal) solutions. The number of such solutions is limited, which greatly simplifies the problem of their choice. Let $X$ be a set of admissible solutions in a given problem, and $x \in X-$ a permissible decision. Let us suppose that every solution $x \in X$ is estimated by $n$ criteria $(n \geq 2)$.

There is a useful solving construction for multicriteria problems - the concept of optimal Pareto or effective solution. Let $H_{i}(x), x \in X$ be a valid function, values of which are solution estimates $x \in X$ on $i$ criteria, where $i=\overrightarrow{1, n}$.

Then vector $H(x)=\left[H_{1}(x), \ldots, H_{i}(x), \ldots, H_{n}(x)\right], x \in X$ is a set of the solution estimates $x \in X$ for all criteria. Let us assume that the advantage degree of the solution $x \in X$ grows with increasing vector $H$ component, that means that when the greater the value $H_{i}(x)$ is, the better solution $x$ on criteria $i, i=\overrightarrow{1, n}$ is. Solution $x^{*} \in X$ is called pareto-optimal (Pareto optimal or effective), if there is no other solution $x \in X$, where $H_{i}(x) \geq H_{i}\left(x^{*}\right), i=\overrightarrow{1, n}$.

In other words, if $x^{*} \in X$ is a pareto-optimal solution, there is no other solution $x \in X$, that can surpass $x^{*}$ at least one of the $n$ criteria, and according to other criteria is not worse.
The concept advantage of an effective solution is that effective solutions exist in practically meaningful classes of problems. The disadvantage of pareto-optimal solution is that it cannot find the only one solution to the problem, you can only get a number of effective solutions.

At the core of the target programming method for solving multi-criteria tasks is the ordering of criteria or goals by degree of importance. The initial problem is solved by successively solving a number of tasks with one target function in such a way that solving a problem with a less important goal cannot worsen the optimal value of the target function with a higher priority. As a result, we get a satisfactory solution for this problem. Target programming, as a rule, applies to linear models. Its main difference from the task of linear programming is that many goals are formalized not as target functions, but as constraints in another more general model. For this, the predicted quantitative values of the target functions and the so-called "deviational variables" are introduced "insufficient" and "redundant", that characterize the degree of achievement of the goals set for this decision. The flexible choice of values for "insufficient" and "redundant" variables allows targeted programming to reach a compromise solution.

There are several targeted programming methods, including weighting method and priority method [10]. In the weighting coefficients method, a single target function is formalized as a weighted sum of output partial objective functions. The disadvantage of this method is the subjectivity of assigning values to weight coefficients, although there are methods that reduce the size of the subjective factor in their choice, such as the Fisher's principle. In the priority method $n$ partial target functions are ranked in order of importance, and then, alternately, the tasks are solved separately with each target function, starting with the function that has the highest priority, and ending with a function that has a minimum priority. In the process of solving tasks, problem solution with a target function that has a lower priority cannot worsen the previously obtained solutions that have a higher priority.

Based on above, it is possible to form three separate target functions of the linear programming task regarding distribution of the investment resource amount of the energy supply enterprise between technological solutions that provide reduction of electricity losses

$$
\begin{aligned}
& \sum_{i=1}^{n} E_{i} \times X_{i} \rightarrow \max \\
& \sum_{i=1}^{n} R_{i} \times X_{i} \rightarrow \max \\
& \sum_{i=1}^{n} M_{i} \times X_{i} \rightarrow \max
\end{aligned}
$$

where $X_{i}$ is the number of units of the $i^{\text {th }}$ type equipment to be replaced by a new one in order to reduce losses in the supply of electricity to consumers, units; $E_{i}$ is annual saving of electric power technological losses in case of the $i^{\text {th }}$ type unit equipment replacement, thousand $\mathrm{UAH} ; R_{i}$ is annual cost savings for unscheduled repairs in case unit of the $i^{\text {th }}$ type replacement, thousand $\mathrm{UAH} ; M_{i}$ is the cost of materials returned from dismantling the old equipment received by the enterprise in case unit of the $i^{\text {th }}$ type replacement, thousand UAH.

All these three target functions are subject to maximization in case of abidance of the following restrictions

$$
\begin{gathered}
\sum_{i=1}^{n} P_{i} \times X_{i} \leq I ; \\
\sum_{i=1}^{n} t_{i} \times X_{i} \leq T ; \\
0 \leq X_{i} \leq N_{i} ; \quad i=\overrightarrow{1, n,}
\end{gathered}
$$


where $P_{i}$ is the cost of the $i^{\text {th }}$ type unit replacement for a new one, thousand UAH; $t_{i}$ is the complexity of the $i^{\text {th }}$ type unit replacement for a new one, man per hour; $N_{i}$ is the amount of $i^{\text {th }}$ type equipment for the replacement, units; $n$ is the number of equipment types for replacement; $I$ is the amount of investment resources for network modernization of the power supply enterprise for the planned period, thousand UAH; $T$ is the maximum possible working time fund of production personnel of the power supply enterprise in the planned period, man per hour.

As was mentioned, in order to move from the linear programming task to the target-programming task, it is necessary to formalize each of our three target functions, as "soft" constraints for another more general model. To make it possible, in the partial target functions it is needed to add variable deviations that characterize the degree of achievement of the goals set for this solution. In target function (1) we need to add two variable deviations $d_{1}^{-}$and $d_{1}^{+}$. Parameter $d_{1}^{-}$is a measure of failure to achieve the goal, and parameter $d_{1}^{+}-$is a measure of exceeding this goal. We add similar variables into the target functions $(2,3)$.

For a fixed index $j$, which corresponds to the number of "soft" constraints or the number of partial targets in the target programming model (in our case $j=3$ ), one of the coefficients $d_{j}^{-}$or $d_{j}^{+}$must be zero, since the target cannot be achieved or exceeded at the same time.

Thus, the new target function of the target-programming task is to minimize the overall deviation from our three goals achievement

$$
d_{1}^{-}+d_{2}^{-}+d_{3}^{+} \rightarrow \min ,
$$

provided adherence to the following "soft" (6) and "rigid" (7) restrictions

$$
\begin{gathered}
\sum_{i=1}^{n} E_{i} \times X_{i}+d_{1}^{-}-d_{1}^{+}=E_{\max } \\
\sum_{i=1}^{n} R_{i} \times X_{i}+d_{2}^{-}-d_{2}^{+}=R_{\max } \\
\sum_{i=1}^{n} M_{i} \times X_{i}+d_{3}^{-}-d_{3}^{+}=M_{\max } \\
\sum_{i=1}^{n} P_{i} \times X_{i} \leq I ; \\
\sum_{i=1}^{n} t_{i} \times X_{i} \leq T ; \\
0 \leq X_{i} \leq N_{i}, \quad i=\overrightarrow{1, n} \\
d_{j}^{-} \geq 0 ; \quad d_{j}^{+} \geq 0 .
\end{gathered}
$$

Maximum values of target functions in (6) $E_{\max }, R_{\max }$ and $M_{\max }$ are determined by the alternating solution of each of the partial tasks of linear programming that are in compliance with restrictions (4).

By forming the target function (5) we assumed that the most important goal for the investigated enterprises is to minimize the level of losses when electricity is supplied to consumers. That is why to the target function the parameter $d_{1}^{-}$is added, which is a measure of failure to achieve the goal in order to minimize its value. For similar reasons, $d_{2}^{-}$is introduced into the target function, since cost saving on unscheduled repairs is of a second priority. We assign the lowest prior-

\begin{tabular}{|c|c|c|c|c|c|c|}
\hline $\begin{array}{l}\text { Type of equipment to be } \\
\text { replaced to reduce loss rate }\end{array}$ & $\begin{array}{c}\text { Yearly } \\
\text { electricity loss } \\
\text { savings }\left(E_{i}\right) \\
\end{array}$ & $\begin{array}{c}\text { Yearly } \\
\text { savings on } \\
\text { repair cost }\left(R_{i}\right)\end{array}$ & $\begin{array}{c}\text { Dismantled } \\
\text { materials cost }\left(M_{i}\right)\end{array}$ & $\begin{array}{l}\text { Single equipment } \\
\text { unit replacement } \\
\text { cost }\left(P_{i}\right)\end{array}$ & $\begin{array}{l}\text { Single equipment } \\
\text { unit replacement } \\
\text { complexity }\left(t_{i}\right) \\
\end{array}$ & $\begin{array}{l}\text { Necessary } \\
\text { replacement } \\
\text { amount }\left(N_{i}\right)\end{array}$ \\
\hline Overhead power line $0.4 \mathrm{kV}$ & $\begin{array}{l}2.54 \text { thousand } \\
\text { UAH/km }\end{array}$ & $\begin{array}{l}2.74 \text { thousand } \\
\text { UAH/km }\end{array}$ & $\begin{array}{l}8.14 \text { thousand } \\
\text { UAH/km }\end{array}$ & $\begin{array}{l}450 \text { thousand } \\
\text { UAH/km }\end{array}$ & $\begin{array}{c}390 \\
\text { human-hour/km }\end{array}$ & $4750 \mathrm{~km}$ \\
\hline $\begin{array}{l}\text { Overhead power line } \\
(10) 6 \mathrm{kV}\end{array}$ & $\begin{array}{l}4.47 \text { thousand } \\
\text { UAH/km }\end{array}$ & $\begin{array}{l}2.50 \text { thousand } \\
\mathrm{UAH} / \mathrm{km}\end{array}$ & $\begin{array}{l}11.30 \text { thousand } \\
\mathrm{UAH} / \mathrm{km}\end{array}$ & $\begin{array}{l}400 \text { thousand } \\
\text { UAH/km }\end{array}$ & $\begin{array}{c}1160 \\
\text { human-hour/km }\end{array}$ & $526 \mathrm{~km}$ \\
\hline $\begin{array}{l}\text { Complete transformer } \\
\text { substation } 6-10 / 0.4 \mathrm{kV}\end{array}$ & $\begin{array}{l}4.50 \text { thousand } \\
\text { UAH/pc. }\end{array}$ & $\begin{array}{l}3.60 \text { thousand } \\
\mathrm{UAH} / \mathrm{pc} \text {. }\end{array}$ & $\begin{array}{l}2.96 \text { thousand } \\
\text { UAH/pc. }\end{array}$ & $\begin{array}{l}100 \text { thousand } \\
\text { UAH/pc. }\end{array}$ & $\begin{array}{c}140 \\
\text { human-hour/pc. }\end{array}$ & 555 pcs. \\
\hline $\begin{array}{l}\text { Replacement of oil-switch } \\
\text { for vacuum } 10 \mathrm{kV} \text { switches }\end{array}$ & $\begin{array}{l}15.33 \text { thousand } \\
\text { UAH/pc. }\end{array}$ & $\begin{array}{l}3.40 \text { thousand } \\
\text { UAH/pc. }\end{array}$ & $\begin{array}{l}1.30 \text { thousand } \\
\text { UAH/pc. }\end{array}$ & $\begin{array}{l}165 \text { thousand } \\
\text { UAH/pc. }\end{array}$ & $\begin{array}{c}485 \\
\text { human-hour/pc. }\end{array}$ & 296 pcs. \\
\hline $\begin{array}{l}\text { Pole transformer substation } \\
40 / 10(6) / 0.4 \mathrm{kV}\end{array}$ & $\begin{array}{l}3.35 \text { thousand } \\
\text { UAH/pc. }\end{array}$ & $\begin{array}{l}4.00 \text { thousand } \\
\text { UAH/pc. }\end{array}$ & $\begin{array}{l}4.80 \text { thousand } \\
\text { UAH/pc. }\end{array}$ & $\begin{array}{l}40 \text { thousand } \\
\text { UAH/pc. }\end{array}$ & $\begin{array}{c}480 \\
\text { human-hour/pc. }\end{array}$ & 6 pcs. \\
\hline $\begin{array}{l}\text { Pole transformer substation } \\
63 / 10(6) / 0.4 \mathrm{kV}\end{array}$ & $\begin{array}{l}2.51 \text { thousand } \\
\mathrm{UAH} / \mathrm{pc} \text {. }\end{array}$ & $\begin{array}{l}5.50 \text { thousand } \\
\mathrm{UAH} / \mathrm{pc} \text {. }\end{array}$ & $\begin{array}{l}5.80 \text { thousand } \\
\text { UAH/pc. }\end{array}$ & $\begin{array}{l}60 \text { thousand } \\
\mathrm{UAH} / \mathrm{pc} \text {. }\end{array}$ & $\begin{array}{c}560 \\
\text { human-hour/pc. }\end{array}$ & 20 pcs. \\
\hline $\begin{array}{l}\text { Pole transformer substation } \\
100 / 10(6) / 0.4 \mathrm{kV}\end{array}$ & $\begin{array}{l}2.28 \text { thousand } \\
\text { UAH/pc. }\end{array}$ & $\begin{array}{l}6.50 \text { thousand } \\
\text { UAH/pc. }\end{array}$ & $\begin{array}{l}7.70 \text { thousand } \\
\text { UAH/pc. }\end{array}$ & $\begin{array}{l}65 \text { thousand } \\
\mathrm{UAH} / \mathrm{pc} \text {. }\end{array}$ & $\begin{array}{c}600 \\
\text { human-hour/pc. }\end{array}$ & 105 pcs. \\
\hline $\begin{array}{l}\text { Pole transformer substation } \\
160 / 10(6) / 0.4 \mathrm{kV}\end{array}$ & $\begin{array}{l}3.76 \text { thousand } \\
\text { UAH/pc. }\end{array}$ & $\begin{array}{l}8.00 \text { thousand } \\
\text { UAH/pc. }\end{array}$ & $\begin{array}{l}10.10 \text { thousand } \\
\text { UAH/pc. }\end{array}$ & $\begin{array}{l}75 \text { thousand } \\
\mathrm{UAH} / \mathrm{pc} \text {. }\end{array}$ & $\begin{array}{c}660 \\
\text { human-hour/pc. }\end{array}$ & 100 pcs. \\
\hline $\begin{array}{l}\text { Pole transformer substation } \\
250 / 10(6) / 0.4 \mathrm{kV}\end{array}$ & $\begin{array}{l}8.60 \text { thousand } \\
\text { UAH/pc. }\end{array}$ & $\begin{array}{l}12.00 \text { thousand } \\
\mathrm{UAH} / \mathrm{pc} \text {. }\end{array}$ & $\begin{array}{l}13.80 \text { thousand } \\
\text { UAH/pc. }\end{array}$ & $\begin{array}{l}85 \text { thousand } \\
\mathrm{UAH} / \mathrm{pc} \text {. }\end{array}$ & $\begin{array}{c}720 \\
\text { human-hour/pc. }\end{array}$ & 60 pcs. \\
\hline $\begin{array}{l}\text { Pole transformer substation } \\
400 / 10(6) / 0.4 \mathrm{kV}\end{array}$ & $\begin{array}{l}9.00 \text { thousand } \\
\text { UAH/pc. }\end{array}$ & $\begin{array}{l}18.00 \text { thousand } \\
\mathrm{UAH} / \mathrm{pc} .\end{array}$ & $\begin{array}{c}16.40 \text { thousand } \\
\mathrm{UAH} / \mathrm{pc} \text {. }\end{array}$ & $\begin{array}{l}116 \text { thousand } \\
\text { UAH/pc. }\end{array}$ & $\begin{array}{c}780 \\
\text { human-hour/pc. } \\
\end{array}$ & 42 pcs. \\
\hline $\begin{array}{l}\text { Pole transformer substation } \\
630 / 10(6) / 0.4 \mathrm{kV}\end{array}$ & $\begin{array}{l}10.24 \text { thousand } \\
\text { UAH/pc. }\end{array}$ & $\begin{array}{l}24.00 \text { thousand } \\
\text { UAH/pc. }\end{array}$ & $\begin{array}{l}22.00 \text { thousand } \\
\text { UAH/pc. }\end{array}$ & $\begin{array}{l}157 \text { thousand } \\
\text { UAH/pc.. }\end{array}$ & $\begin{array}{c}860 \\
\text { human-hour/pc. }\end{array}$ & 14 pcs. \\
\hline
\end{tabular}
ity to maximize the cost of recycled materials from old equipment, because unlike the previous two, there are one-time receipts for an energy supply company, not annual ones. Therefore, parameter $d_{3}^{+}$is included into the target function, which

Table

Initial values of PJSC "Prykarpattiaoblenerho" investment resources targeted programming model parameters between technical and technological solutions to provide operational cost decrease during electricity delivery [7]

Total amount of allocated investments per year: $I=204410$ thousand UAH.

The number of electricians, involved in electricity grid exploitation - 485 pers., which is equivalent to maximum possible working hours fund $T=804130$ human-hours 
is a measure of exceeding this goal. Thus, this confirms that the achievement of this goal is not the most important for us.

Based on "Prykarpattiaoblenerho" data, we form Table with values for target programming of investment resources distribution at this enterprise for the next year.

Formed on these data, the target-programming model is best to solve with Excel editor, using the help of the "Search Solution". First, we calculate three separate linear functions of each of the purposes for finding the right parts of the "soft" restrictions (6).

As an example, Fig. 1 shows a model for maximizing savings from the reduction of technological energy losses generated by Excel. The value of this target function is 9562.84 thousand UAH. Similarly, target functions for the following two criteria are formed.

The results of the calculations made it possible to set the parameters of "soft" model constraints at the following level: $E_{\max }=9562.84$ thousand $\mathrm{UAH} ; R_{\max }=6882.9$ thousand $\mathrm{UAH}$; $M_{\max }=8845.92$ thousand UAH.
The next step is to solve the target-programming model, which is presented in Fig. 2.

According to the above inputs, in order to comply with all constraints, investment and labor resources must be allocated among the different types of equipment to be replaced in order to reduce the energy supply enterprise losses, as follows: overhead power line $0.4 \mathrm{kV}-0 \mathrm{~km}$; overhead power line (10)6 kV $180 \mathrm{~km}$; complete transformer substation $6-10 / 0.4 \mathrm{kV}-$ 555 pcs.; replacement of oil on vacuum switches $10 \mathrm{kV}-$ $296 \mathrm{pcs}$. and the replacement of all seven types of power transformers to the required extent.

With this investment resources distribution "Prykarpattiaoblenerho" will achieve 24295.44 thousand UAH savings during a planned year and electricians' workload will be $82.2 \%$.

At the beginning of the next planned periods the target programing procedure concerning investment resources allocation should be carried out by enterprise repeatedly, based on new values of the input data of the model.

\begin{tabular}{|c|c|c|c|c|c|c|c|c|c|c|}
\hline$\Delta$ & A & B & $\mathrm{C}$ & $\mathrm{D}$ & $\mathrm{E}$ & $\mathrm{F}$ & G & $\mathrm{H}$ & I & $\Delta$ \\
\hline 3 & $\begin{array}{c}\text { Type of equipment underlying replacement to } \\
\text { reduce loss rate }\end{array}$ & $\begin{array}{c}\text { Yearly } \\
\text { electricity } \\
\text { loss } \\
\text { savings }\end{array}$ & $\begin{array}{l}\text { Estimated } \\
\text { equipment } \\
\text { amount of } \\
\text { each kind }\end{array}$ & $\begin{array}{c}\text { Target } \\
\text { function } \\
\text { components }\end{array}$ & $\begin{array}{c}\text { Single } \\
\text { equipment } \\
\text { unit } \\
\text { replace- } \\
\text { ment cost }\end{array}$ & $\begin{array}{c}\text { Constituents } \\
\text { of } \\
\text { investment } \\
\text { restrictions }\end{array}$ & $\begin{array}{c}\text { Single } \\
\text { equipment } \\
\text { unit repla- } \\
\text { cement } \\
\text { com- } \\
\text { plexity }\end{array}$ & $\begin{array}{l}\text { Consti- } \\
\text { tuents of } \\
\text { complexi- } \\
\text { ty restric- } \\
\text { tions }\end{array}$ & $\begin{array}{c}\text { Necessa- } \\
\text { ry replace- } \\
\text { ment } \\
\text { amount }\end{array}$ & \\
\hline 6 & Overhead power line (10)6 kV & 4,47 & 180 & 804,6 & 400 & 72000 & 1160 & 208800 & 526 & \\
\hline 7 & Complete transformer substation $6-10 / 0.4 \mathrm{kV}$ & 4,5 & 555 & 2497,5 & 100 & 55500 & 140 & 77700 & 555 & \\
\hline 8 & Replacement olir for vacuum $10 \mathrm{kV}$ switches & 15,33 & 296 & 4537,68 & 165 & 48840 & 485 & 143560 & 296 & \\
\hline 9 & Pole transformer substation $40 / 10(6) / 0.4 \mathrm{kV}$ & 3,35 & 6 & 20,1 & 40 & 240 & 480 & 2880 & 6 & \\
\hline 10 & Pole transformer substation $63 / 10(6) / 0.4 \mathrm{kV}$ & 2,51 & 20 & 50,2 & 60 & 1200 & 560 & 11200 & 20 & \\
\hline 11 & Pole transformer substation $100 / 10(6) / 0.4 \mathrm{kV}$ & 2,28 & 105 & 239,4 & 65 & 6825 & 600 & 63000 & 105 & \\
\hline 15 & Pole transformer substation $630 / 10(6) / 0.4 \mathrm{kV}$ & 10,24 & 14 & 143,36 & 157 & 2198 & 860 & 12040 & 14 & \\
\hline \multicolumn{11}{|c|}{16} \\
\hline 17 & \multicolumn{3}{|c|}{ The value of the target function } & 9562,84 & & 204275 & & 661140 & & \\
\hline \multicolumn{11}{|c|}{ 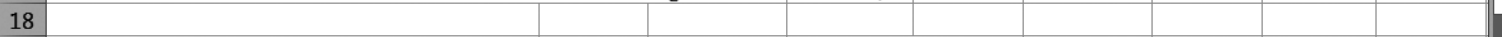 } \\
\hline 19 & & & & \multicolumn{2}{|c|}{ Restrictions } & 204410 & & 804130 & & $\nabla$ \\
\hline 4 & - ... Target_function_1 & Targe & t_function_3 & $\ldots \oplus \vdots$ & \begin{tabular}{l|l|l|}
$\vdots$ & 1 & \\
\end{tabular} & & & & D & \\
\hline
\end{tabular}

Fig. 1. Excel-based model of savings maximization from technological electricity loss

\begin{tabular}{|c|c|c|c|c|c|c|c|c|c|c|c|c|c|c|}
\hline$\Delta$ & A & B & C & D & E & $\mathrm{F}$ & G & $\mathrm{H}$ & I & J & $\mathrm{K}$ & $\mathrm{L}$ & M & $\Delta$ \\
\hline 3 & \multirow[t]{2}{*}{$\begin{array}{l}\text { Type of equipment underlying replacement to } \\
\text { reduce loss rate }\end{array}$} & $\begin{array}{c}\text { Yearly } \\
\text { electricity } \\
\text { loss } \\
\text { savings }\end{array}$ & $\begin{array}{l}\text { Estimated } \\
\text { equipment } \\
\text { amount of } \\
\text { each kind }\end{array}$ & $\begin{array}{c}\text { Consti- } \\
\text { tuents of } \\
\text { soft limita- } \\
\text { tions on } \\
\text { losses }\end{array}$ & $\begin{array}{c}\text { Yearly } \\
\text { savings } \\
\text { on repair } \\
\text { cost }\end{array}$ & $\begin{array}{c}\text { Consti- } \\
\text { tuents of } \\
\text { soft limita- } \\
\text { tions on } \\
\text { repair cost }\end{array}$ & $\begin{array}{c}\text { Dismantled } \\
\text { materials } \\
\text { cost }\end{array}$ & \begin{tabular}{|c|} 
Soft \\
limitation \\
components \\
for returned \\
materials \\
cost \\
\end{tabular} & $\begin{array}{c}\text { Single } \\
\text { equipment } \\
\text { unit repla- } \\
\text { cement } \\
\text { cost }\end{array}$ & $\begin{array}{c}\text { Consti- } \\
\text { tuents of } \\
\text { investment } \\
\text { restrictions }\end{array}$ & \begin{tabular}{|c|} 
Single \\
equipment \\
unit repla- \\
cement \\
com- \\
plexity
\end{tabular} & $\begin{array}{c}\text { Consti- } \\
\text { tuents of } \\
\text { complexi- } \\
\text { ty restric- } \\
\text { tions }\end{array}$ & $\begin{array}{c}\text { Necessa- } \\
\text { ry replace- } \\
\text { ment } \\
\text { amount }\end{array}$ & \\
\hline 4 & & $\left(E_{i}\right)$ & $\left(X_{i}\right)$ & $\left(E_{i} X_{i}\right)$ & $\left(R_{i}\right)$ & $\left(R i^{\prime} X_{i}\right)$ & $\left(M_{i}\right)$ & $\left(M i X_{i}\right)$ & $\left(P_{i}\right)$ & $\left(P_{i} X_{i}\right)$ & $\left(t_{i}\right)$ & $\left(t_{i} X_{i}\right)$ & $\left(N_{i}\right)$ & \\
\hline 5 & Overhead power line $0.4 \mathrm{kV}$ & 2,54 & 0 & 0 & 2,74 & 0 & 8,14 & 0 & 450 & 0 & 390 & 0 & 4750 & \\
\hline 6 & Overhead power line $(10) 6 \mathrm{kV}$ & 4,47 & 180 & 804,6 & 2,5 & 450 & 11,3 & 2034 & 400 & 72000 & 1160 & 208800 & 526 & \\
\hline 7 & Complete transformer substation 6-10/0.4 kV & 4,5 & 555 & 2497,5 & 3,6 & 1998 & 2,96 & 1642,8 & 100 & 55500 & 140 & 77700 & 555 & \\
\hline 8 & Replacement olir for vacuum $10 \mathrm{kV}$ switches & 15,33 & 296 & 4537,68 & 3,4 & 1006,4 & 1,3 & 384,8 & 165 & 48840 & 485 & 143560 & 296 & \\
\hline 9 & Pole transformer substation $40 / 10(6) / 0.4 \mathrm{kV}$ & 3,35 & 6 & 20,1 & 4 & 24 & 4,8 & 28,8 & 40 & 240 & 480 & 2880 & 6 & \\
\hline 10 & Pole transformer substation $63 / 10(6) / 0.4 \mathrm{kV}$ & 2,51 & 20 & 50,2 & 5,5 & 110 & 5,8 & 116 & 60 & 1200 & 560 & 11200 & 20 & \\
\hline 11 & Pole transformer substation $100 / 10(6) / 0.4 \mathrm{kV}$ & 2,28 & 105 & 239,4 & 6,5 & 682,5 & 7,7 & 808,5 & 65 & 6825 & 600 & 63000 & 105 & \\
\hline 12 & Pole transformer substation $160 / 10(6) / 0.4 \mathrm{kV}$ & 3,76 & 100 & 376 & 8 & 800 & 10,1 & 1010 & 75 & 7500 & 660 & 66000 & 100 & \\
\hline 13 & Pole transformer substation $250 / 10(6) / 0.4 \mathrm{kV}$ & 8,6 & 60 & 516 & 12 & 720 & 13,8 & 828 & 85 & 5100 & 720 & 43200 & 60 & \\
\hline 14 & Pole transformer substation $400 / 10(6) / 0.4 \mathrm{kV}$ & 9 & 42 & 378 & 18 & 756 & 16,4 & 688,8 & 116 & 4872 & 780 & 32760 & 42 & \\
\hline 15 & Pole transformer substation $630 / 10(6) / 0.4 \mathrm{kV}$ & 10,24 & 14 & 143,36 & 24 & 336 & 22 & 308 & 157 & 2198 & 860 & 12040 & 14 & \\
\hline 16 & Variable deviations $d_{j}^{-}$ & & 0,00 & 0 & 0,00 & 0 & 996,22 & 996,22 & & & & & & \\
\hline 17 & Variable deviations $d_{j}^{+}$ & & 0,00 & 0 & 0,00 & 0 & 0,00 & 0 & & & & & & \\
\hline \multicolumn{15}{|c|}{18} \\
\hline 19 & The value of the target function & 0,00 & & & & & & & & & & & & \\
\hline 20 & & & & 9562,84 & & 6882,90 & & 8845,92 & & 204275 & & 661140 & & \\
\hline \multicolumn{15}{|l|}{21} \\
\hline 22 & & & Restrictions & 9562,84 & & 6882,90 & & 8845,92 & & 204410 & & 804130 & & \\
\hline \multicolumn{15}{|l|}{23} \\
\hline 24 & Achieved savings in losses and costs & 24295,44 & & & & The level of & loading of $\mathrm{e}$ & lectricians ser & rvicing the & power grid, & & 82,2 & & $\nabla$ \\
\hline 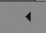 & \begin{tabular}{ll|l}
,$\ldots$ & Target_function_1
\end{tabular} & Target_f & function_3 & Target_fun & inction_TP & $\oplus$ & $\vdots \mathbf{1}$ & & & & & & & \\
\hline
\end{tabular}

Fig. 2. Excel-based model of target programming for minimizing energy supplying enterprise loss during electricity transfer 
Conclusions. Based on changes taking place in the energy sector $[9,10]$, the problem of reducing operational losses while transporting electricity has not lost its relevance, but on the contrary has taken one of the main tasks of ensuring financial stability of energy supply companies. Theoretical principles and practical recommendations for choosing a better solution to reduce operational losses of power supply enterprises become very important. The solutions choice is proposed to be implemented from the system of alternative solutions (organizational and managerial, administrative and technological, technical and technological decisions) by comparing their efficiency at the given time for the energy supply enterprise.

Since technical and technological solutions mostly depict the loss reduction rate, the authors suggested looking further into it, as well as target function model for resource distribution between these solutions was proposed. Therefore, the proposed target-programming model will provide the possibility to obtain the most effective solutions for energy supplying enterprises in terms of operational cost minimization during the energy delivery process to the end customers.

However, this model refers only to reasoning technical and technological solutions for operational cost decreasing during electricity transportation, thus the further research refers to development and approbation optimization models for organization and technical management solutions.

\section{References.}

1. Astashev, D. S., Bedretdinov, R. S., Kisel, D. A., \& Sosnina, E. N. (2015). Application of voltage of $20 \mathrm{kV}$ for distribution electrical networks. Vestnik NGEI, (4), 6-9.

2. Kostetska, N. I. (2014). Methodological Approaches to Cost Planning in the Enterprise. In V.I.Grinchuk (Ed.) (2014). Transformation processes of the economic system in the context of modern challenges: monograph. (pp. 446-456). Ternopil: Step. 3. Kostetska, N. I. (2017). Features of the mechanism of strategic management of expenses of the enterprise. Innovative economy, 5-6(69), 91-96.

4. Levytska, I. O. (2014). Audit of costs for the transmission and/or supply of electricity to energy supply companies. Strategic decisions of information development of economy, society and business. In Abstracts of the III International reports. sci. pract. conf. Rivne: NUVGP (pp. 140-143.) Retrieved from https://ecj.oa.edu.ua/articles/2014/n26/19. pdf.

5. Levytska, I. O. (2012). Information support for cost formation of energy supply company: accounting and analytical approach. Bulletin of the L'viv Polytechnic National University. Management and Entrepreneurship in Ukraine, (797), 85-92. Retrieved from http://vlp.com.ua/node/13237.

6. Filippova, S. V., \& Yudin, M.A. (2016). Trends in the domestic energy market and alternative energy. Economy: Realities of Time. Scientific Journal, 5(27), 5-10.

7. Program for the development of electric networks with voltage 35-110 (150) $\mathrm{kV}$ and determination of volumes of reconstruction of electric networks with voltage 0.4-10 kV for 2016-2020 years PJSC "Prykarpattiaoblenerho" Retrieved from https://oe.if. ua/uploads/question_document/document/5af93402db9c42 0b5c7e4193/poloj_gal_rem_.pdf.

8. DTEK Integrated Report for 2017. Retrieved from http:// www.dtek.com/library/file/annual-report2017-ua.pdf.

9. National Institute for Strategic Studies under the President of Ukraine (2014). The White Paper of Ukraine's Energy Policy 'Security and Competitiveness" (Energy Strategy of Ukraine for the period up to 2035). Retrieved from http://www.niss.gov.ua/ public/File/2014_nauk_an_rozrobku/Energy\%20Strategy\%2020 35.pdf.

10. Energy Road Map 2050. Retrieved from http://eurlex.europa.eu/LexUriServ/LexUriServ.do?uri=CELEX:52011DC0 885:EN:NOT.

\section{Методичні підходи до розподілу ресурсів енергопостачального підприємства щодо зменшення операційних втрат}

\author{
H. I. Чухрай, О. 3. Сорочак, I. В. Бохонко
}

Національний університет „Львівська політехніка“, м. Львів, Україна, e-mail: chuhraj@polynet.lviv.ua

Незважаючи на значну кількість праць провідних українських і зарубіжних учених щодо зменшення операційних втрат при передаванні електроенергії, доцільність подальшого дослідження обумовлюється зростаючою потребою розподілу інвестиційних ресурсів між технікотехнологічними рішеннями так, щоб досягти оптимального вирішення цієї багатоцільової проблеми.

Мета. Розроблення та апробація моделі цільового програмування для оптимального розподілу інвестиційних ресурсів енергопостачального підприємства між різними варіантами техніко-технологічних рішень щодо зменшення операційних втрат при транспортуванні електроенергії від джерел ії̈ генерації до споживачів.

Методика. Авторами застосовані системний та аналітичний метод, метод цільового програмування, шо дає можливість розподілити інвестиційні ресурси енергопостачального підприємства.

Результати. Оскільки техніко-технологічні рішення відображають показник зменшення втрат, авторами запропоновано розглянути їх детальніше. Розроблена модель цільового програмування розподілу ресурсів між цими рішеннями. Таким чином, запропонована модель цільового програмування забезпечуватиме можливість прийняття найбільш ефективних рішень керівництвом енергопостачальних підприємств щодо мінімізації операційних втрат під час постачання електроенергії споживачам.

Наукова новизна. Розроблена модель оптимального розподілу інвестиційних ресурсів між техніко-технологічними рішеннями щодо зменшення операційних втрат при постачанні електроенергії. Дана модель дозволяє розподілити інвестиційні ресурси таким чином, щоб задовільнити обрані критерії оптимізації й досягнути найкращого результату для енергопостачального підприємства.

Практична значимість. Запропонована модель запроваджена на енергопостачальному підприємстві ПАТ „Прикарпаттяобленерго“, а отримані результати дають змогу розв'язати проблеми зниження втрат електроенергії при транспортуванні.

Ключові слова: електроенергія, транспортування електроенергії, операційні втрати, енергопостачальне підприємство, техніко-технологічне рішення, лінійне програмування, цільове програмування

\section{Методические подходы к распределению ресурсов энергоснабжающего предприятия по уменышению операционных потерь}

\section{Н. И. Чухрай, О. З. Сорочак, И. В. Бохонко}

Национальный университет „Львовская политехника“, г. Львов, Украина, e-mail: chuhraj@polynet.lviv.ua

Несмотря на значительное количество работ ведущих украинских и зарубежных ученых по уменьшению операционных потерь при передаче электроэнергии, целесообразность дальнейшего исследования определяется возрастающей потребностью распределения инвестиционных ресурсов между технико-технологическими решениями так, чтобы достичь оптимального решения этой многоцелевой проблемы. 
Цель. Разработка и апробация модели целевого программирования для оптимального распределения инвестиционных ресурсов энергоснабжающего предприятия между различными вариантами технико-технологических решений по уменьшению операционных потерь при транспортировке электроэнергии от источников ее генерации к потребителям.

Методика. Авторами применены системный и аналитический метод, метод целевого программирования, что позволяет распределить инвестиционные ресурсы энергоснабжающего предприятия.

Результаты. Поскольку технико-технологические решения отражают показатель уменьшения потерь, авторами предложено рассмотреть их подробнее. Разработана модель целевого программирования распределения ресурсов между этими решениями. Таким образом, предложенная модель целевого программирования обеспечивает возможность принятия наиболее эффективных решений руководством энергоснабжающих предприятий по минимизации операционных потерь при поставке электроэнергии потребителям.
Научная новизна. Разработана модель оптимального распределения инвестиционных ресурсов между технико-технологическими решениями по уменьшению операционных потерь при поставке электроэнергии. Данная модель позволяет распределить инвестиционные ресурсы таким образом, чтобы удовлетворить выбранные критерии оптимизации и достичь наилучшего результата для энергоснабжающего предприятия.

Практическая значимость. Предложенная модель внедрена на энергоснабжающем предприятии ПАО „Прикарпатьеоблэнерго“, а полученные результаты позволяют решить проблемы снижения потерь электроэнергии при транспортировке.

Ключевые слова: электроэнергия, транспортировка электроэнергии, операционные потери, энергоснабжающее предприятие, технико-технологическое решение, линейное программирование, целевое программирование

Рекомендовано до публікації докт. екон. наук О. I. Карим. Дата надходження рукопису 21.10.18. 